\title{
Variation in detrital enrichment causes spatio- temporal variation in soft-sediment assemblages
}

\author{
Brendan P. Kelaher, Jeffrey S. Levinton*
}

Department of Ecology and Evolution, State University of New York, Stony Brook, New York 11974-5245, USA

\begin{abstract}
We investigated the importance of algal detritus in determining complex patterns of spatio-temporal variation in annelid assemblages in sites separated by 10s of meters on mudflats on Long Island, New York. We used field sampling to test the hypothesis that spatio-temporal variation in annelid assemblages contributes substantially more to total variation than consistent spatial differences among sites (pure spatial variation). While this pattern was generally shown by dominant surface-feeding annelids (e.g. Paranais litoralis and Streblospio benedicti), this was not the case for the deeper-feeding orbinid polychaete Leitoscolopolos robustus. We enriched the sediment with Ulva rotundata detrius to test the hypothesis that variation in detrital enrichment creates complex spatio-temporal patterns in annelid assemblages. Initially, the diversity and abundance of annelids was lower in enriched sites compared to untouched sites because of anoxic conditions at the sediment-water interface in the manipulated treatment. After about $1 \mathrm{mo}$, however, populations of opportunistic surface-feeding annelids (e.g. P. litoralis and Capitella capitata) increased in enriched sites to peak significantly higher than those in unmanipulated sediment, indicating resourcelimitation. The annelid assemblages in different treatments then converged in June/July when the excess detrital resources were sufficiently depleted. Overall, we demonstrate the important role that deposition of detritus plays in determining variation in soft-sediment communities. More than just simple spatial variation, however, we show that detritus enrichment can generate the complicated spatio-temporal patterns observed in natural annelid assemblages.
\end{abstract}

KEY WORDS: Variation $\cdot$ Soft sediment $\cdot$ Macrofauna $\cdot$ Detritus $\cdot$ Ulva rotundata Resale or republication not permitted without written consent of the publisher

\section{INTRODUCTION}

The composition of most benthic marine communities is extremely variable in space and time (Barry \& Dayton 1991, Morrisey et al. 1992a,b, Underwood \& Chapman 1998). Although this variation occurs at a hierarchy of different scales (Thrush 1991, Underwood \& Chapman 1996, Azovsky et al. 2000), there is a growing awareness of the relative importance of variation among sites separated by 10 s of meters in many benthic marine habitats (e.g. soft sediments: Morrisey et al. 1992a, mangroves: Chapman 1998, rocky shores: Olabarria \& Chapman 2001). This intermediate-scale variation is often considered a nuisance because it obscures processes governing community structure and increases the need for replication at this scale (Underwood 1994, Kelaher et al. 2001). Nevertheless, understanding biological and environmental processes that cause variation at this scale is essential for developing ecological generalizations and for sensibly scaling up predictive models to those important for managing natural environments.

Like other marine benthic communities, softsediment assemblages dominated by deposit-feeders generally exhibit spatial variation among sites separated by 10s of meters (Thrush 1991, Morrisey et al. 1992a, Zajac 2001). In many cases this variation has been explained by small-scale differences in the physical environment or in biotic interactions (e.g. sediment, grain size, predation or competition; see Gray 1974, Woodin 1974, Olafsson et al. 1994 for reviews). Nevertheless, these simple relations often prove insufficient to completely explain inter-site variation (Snelgrove \& Butman 1994). 
An alternative explanation for intermediate-scale variation emerges from the work of Johnson (1970), who saw soft-sediment habitats as a spatial landscape of patches with different elapsed periods since disturbance. Rhoads et al. (1978) also described small-scale disturbances, such as sediment deposition or eutrophication, as a mechanism of initiation of communities consisting of deposit-feeding species that relied on seasonal deposition of detritus at the sediment-water interface. Subsequent studies have shown that these simple successional sequences are more nonlinear than initially predicted because of complex spatial relationships (Thrush et al. 1996, Whitlatch et al. 1998, Zajac 2001), variation in patterns of recruitment (Olafsson et al. 1994) and interactions among sedimenthydrodynamic factors (Snelgrove \& Butman 1994). Despite this, it has become abundantly clear that small-scale/short-term perturbations have the potential to cause substantial spatio-temporal variation in the structure of macrobenthic assemblages in softsediment habitats at intermediate scales (Thistle 1981, Thrush et al. 1996).

Benthic communities on intertidal mudflats near saltmarshes are generally dominated by deposit-feeding invertebrates (Levin 1984, Lopez \& Levinton 1987). Biotic interactions in these habitats are fueled by inputs of detrital material from a number of sources, including saltmarshes, macroalgae or phytoplankton (see Nixon 1980 for review). Some of this organic detritus is consumed directly by deposit-feeding organisms (Findlay \& Tenore 1982, Peterson et al. 1986). Bacteria then break down much of the remaining material (Rublee 1982), which in turn provides nutrients for other benthic microorganisms (e.g. diatoms) that are directly consumed by deposit-feeders. These microorganisms are a major source of nutrition for depositfeeding invertebrates that feed near the sedimentwater interface (Bianchi \& Levinton 1981, Findlay \& Tenore 1982, Lopez \& Levinton 1987).

Because the population abundances of common deposit-feeders are often limited by the availability of algal detritus (Levinton \& Stewart 1982, 1988, Lopez \& Levinton 1987), spatial and temporal variation in its deposition can create variation in benthic community structure (Hull 1987, Raffaelli et al. 1998, Bolam et al. 2000, Rossi \& Underwood 2002). The effects of detritus enrichment can be further complicated by short-term anoxic events that occur at the sediment-water interface when enrichment is excessive (Wharfe 1977, Levinton \& Stewart 1988, Tagliapietra et al. 1998). Anoxic conditions in surface sediments can substantially reduce the diversity and abundance of macrofauna (Diaz \& Rosenberg 1995, Tagliapietra et al. 1998). When this sediment eventually becomes oxygenated, however, a large amount of nutrients become available for micro- and macrofaunal population growth compared to areas where detritus-induced anoxia has not occurred (Levinton \& Stewart 1988, Bianchi et al. 2000). Localized detrital enrichment of soft sediments, therefore, has the potential to substantially increase spatio-temporal variation of faunal assemblages (Rhoads et al. 1978, Rossi \& Underwood 2002).

Our study is based on previous laboratory studies that demonstrated that detrital inputs stimulate flushcrash cycles of deposit-feeding annelids (Tenore 1977, Levinton \& Stewart 1982, 1988, Tenore \& Chesney 1985). Cheng et al. (1993) connected these laboratory results to seasonal flush-crash cycles of annelids in salt-marsh mudflats of Long Island, New York. On these flats, the oligochaete Paranais litoralis and the polychaete Streblospio benedicti show strong population peaks in the spring, followed by rapid declines in the early summer. During this period, the nutritional content of the sediment declines substantially, as evidenced by steadily declining percentage assimilation of carbon and the successively reduced ability of the sediment to support population growth of $P$. litoralis in the laboratory (Cheng et al. 1993). As well as showing strong seasonal patterns of abundance, these common annelids also show substantial spatial variation at intermediate scales (Nilsson et al. 1997, B. P. Kelaher et al. unpubl. data). While it is possible that this variation is maintained consistently throughout the large seasonal changes, the biology of these organisms suggests that differences in abundance among sites must change through time (Levin 1984, Nilsson et al. 1997, 2000).

To address this, we investigated spatio-temporal variation of annelid assemblages in sites separated by 10s of meters on mudflats on Long Island, New York. We focused on annelids because they generally account for more than $90 \%$ of the total macrofaunal abundance (J. S. Levinton unpubl. data). In the first part of this study, we used field sampling to evaluate patterns of annelid assemblage development by testing the hypothesis that assemblages vary significantly among sites separated by 10 s of meters, as well as through time. Following the predictions of Johnson (1970), we also tested the hypothesis that most of this variation is caused by changes in average assemblage structures in sites relative to each other over time (spatio-temporal variation), rather than by sites remaining consistently different over time (pure spatial variation). In the second part, we used field experiments to test the hypothesis that detrital enrichment is the driving force in altering abundances of deposit-feeders and is contributing substantially to spatio-temporal patterns of species abundance and composition. 


\section{MATERIALS AND METHODS}

Description of study site. This study was done on intertidal mud flats at Flax Pond, Long Island, New York, USA (see Levinton \& Bianchi 1981 for description). These mud flats are typical of those found in southern New England, USA, and are surrounded by salt-marsh, dominated by Spartina alterniflora. Decomposing algae organically enriches surface sediments on these flats. The biomass and species composition of the algae is variable throughout the year, although the green alga Ulva rotundata is generally the most abundant species on the mud flat (Levinton \& Stewart 1982). Detrital resources in the sediment are especially high in early spring because of the low levels of benthic activity over winter (Levinton 1985, Cheng et al. 1993). As temperatures increase in March and April, small patches $(<1 \mathrm{~m})$ of white sulfur bacteria appear on the surface of the mud in some places, indicating anoxic conditions just below the sedimentwater interface. These patches rarely persist into May (J. S. Levinton pers. obs.).

Variation in annelid assemblages. To test the hypothesis that annelid communities at Flax Pond are variable in space and time, 4 sites $(2 \times 2 \mathrm{~m})$ were haphazardly selected at similar tidal heights. Each site was located approximately 10 to $15 \mathrm{~m}$ from its nearest neighbor. All sites were sampled 13 times between 10 May 2001 and 4 January 2002 at approximately 3 wk intervals. On each day of sampling, 5 randomlyplaced cores $(5 \mathrm{~cm}$ in diameter and $5 \mathrm{~cm}$ deep, $\sim 100 \mathrm{~cm}^{3}$ ) were collected from each site. Each core was washed in a $500 \mu \mathrm{m}$ sieve, and the material retained was preserved in a $7 \%$ formalin solution. The material from each sieved core was then carefully sorted under $\times 16$ magnification and all annelids identified to species.

Effects of surface anoxia on structure of annelid assemblages. To test the hypothesis that detrital addition affects annelid communities, a manipulative experiment was set up in March 2002. We haphazardly selected 3 plots $\left(0.25 \mathrm{~m}^{2}\right)$, about $15 \mathrm{~m}$ apart, and handchurned $52 \mathrm{~g}$ of dried shredded Ulva rotundata into the upper $3 \mathrm{~cm}$ of sediment of each plot. This amount of $U$. rotundata represents the average biomass $\mathrm{m}^{-2}$ deposited under $U$. rotundata patches over the winter period on the mud flats at Flax Pond (Levinton \& Stewart 1988). Laboratory studies have shown that adding this quantity of $U$. rotundata detritus to Flax Pond sediment often causes anoxic conditions at the sediment-water interface for approximately 2 to $3 \mathrm{wk}$ (Levinton \& Stewart 1982). The $U$. rotundata for this and other experiments (see below) was collected live from nearby areas and had a mean $(\mathrm{SD}, \mathrm{n}=2) \mathrm{C}: \mathrm{N}$ ratio of $7.62(0.10)$, which was slightly lower than that of
$U$. rotundata washed up on the mud flat $(\mathrm{C}: \mathrm{N}$ ratio $=$ $7.90[0.09])$.

After a period of $4 \mathrm{wk}$ following the addition of Ulva rotundata, 3 more plots $\left(0.25 \mathrm{~m}^{2}\right)$ were chosen in places that had white sulfur bacteria on the surface of the sediment, indicating anoxic conditions. On these flats, patches of white sulfur bacteria were often comparable in size to discrete patches of $U$. rotundata, and it is probable that these factors are linked. Another 3 plots were also haphazardly chosen in areas with no white sulfur bacteria present; 3 randomly placed cores $(5 \mathrm{~cm}$ in diameter and $5 \mathrm{~cm}$ deep, $100 \mathrm{~cm}^{3}$ ) were collected from each plot. Each core was sieved and the annelids were quantified using the methods described above. A control treatment to test for the disturbance of adding $U$. rotundata was not included, because previous work had indicated that this manual disturbance had no detectable impact on annelid assemblages (Kelaher et al. 2003, see also third subsection of 'Results').

Effect of detrital enrichment on development of annelid assemblages. To test the hypotheses that detrital input changes the space-time trajectory of annelid assemblages, another manipulative experiment was set up in March 2002. Eight sites $\left(1 \mathrm{~m}^{2}\right)$ were haphazardly selected at similar tidal heights and randomly allocated to 3 treatments: an Ulva rotundata-enriched treatment ( 3 sites), an untouched treatment (3 sites) and a disturbance control (2 sites). Each site was approximately $5 \mathrm{~m}$ from its nearest neighbor and at a similar tidal height. We hand-churned $208 \mathrm{~g}$ of dried shredded $U$. rotundata into the sediment of each site in the detritus-enrichment treatment. This amount of $U$. rotundata was equivalent per unit area to the amounts used in the detrtial enrichment experiment described above. To control for the manual disturbance of adding $U$. rotundata, sediment in disturbance sites was also hand-churned, but no detritus was added. Only 2 plots were used in this treatment because previous work had indicated that manual disturbances had few lasting effects on macrofauna (B. P. Kelaher et al. unpubl. data).

Annelid assemblages at each site were sampled 6 times after addition of Ulva rotundata at approximately 2 wk intervals. The experiment was limited to spring because this is the most dynamic period for annelid assemblages at this site (Cheng et al. 1993). At each time of sampling, 4 randomly placed cores $(5 \mathrm{~cm}$ in diameter and $5 \mathrm{~cm}$ deep, $100 \mathrm{~cm}^{3}$ ) were collected from each plot. To reduce the effects of repeated sampling, each core was collected from a spot that had not been previously sampled. Sampling was also done from wooden planks to reduce trampling disturbance around the plots. Each core was sieved and the annelids quantified using the methods described above. 
Table 1. NP-MANOVAs of assemblages of annelids ( $\mathrm{n}=5$ replicate cores) sampled between May 2001 and January 2002. T: comparison between randomly chosen sampling dates; $\mathrm{S}$ : comparison between randomly chosen sites; Res: residual. Table also shows components of variation (V) calculated using NP-MANOVA results and traditional methods (see Underwood 1997)

\begin{tabular}{|lrrcrr|}
\hline & df & MS & pseudo- $F$ & p & \\
\hline $\mathrm{T}$ & 12 & 13074.32 & 3.27 & $\mathbf{< 0 . 0 1}$ & $\mathrm{V}_{\mathrm{T}}=20.1$ \\
$\mathrm{~S}$ & 3 & 16735.86 & 4.18 & $\mathbf{< 0 . 0 1}$ & $\mathrm{V}_{\mathrm{S}}=8.7$ \\
$\mathrm{~T} \times \mathrm{S}$ & 36 & 4003.99 & 4.00 & $\mathbf{< . 0 1}$ & $\mathrm{V}_{\mathrm{T} \times \mathrm{S}}=26.7$ \\
Res & 208 & 1001.73 & & & $\mathrm{~V}_{\text {res }}=44.5$ \\
& & & & & \\
\hline
\end{tabular}

Statistical analyses. Analyses of variance (ANOVA) were used to test hypotheses about the number of annelid species and the abundance of the most common species. Student-Newman-Keuls (SNK) tests were used for a posteriori comparisons among means. The variances of abundance of common annelids were mostly heterogeneous (Cochran's $C$-tests, $\mathrm{p}<0.05)$. To reduce heteroscedasticity, these data were transformed using a $\ln (x+1)$ function prior to analysis (Underwood 1997). Unbalanced ANOVAs were used to test for effects of sediment disturbance on annelids (Winer et al. 1991). Univariate components of variation were estimated using the residual maximum-likelihood method (see Robinson 1987).

Non-parametric multivariate analyses of variance (NP-MANOVA) were used to test hypotheses about differences in annelid assemblages (Anderson 2001, McArdle \& Anderson 2001). These analyses test for overall multivariate changes in community structure, which may include differences in composition, richness and/or abundance of individual species. Non-metric multidimensional scaling (nMDS, Field et al. 1982)

was used to produce 2-dimensional ordination plots that tracked relationships among assemblages of annelids through time. For these analyses, data were averaged across sites. All multivariate analyses were done using BrayCurtis similarity coefficients (Bray \& Curtis 1957).

For all analyses, time of sampling was considered a random factor (see Underwood 1997). As a consequence, there was no exact test for comparisons among treatments in the experiment investigating the effects of detritus enrichment on spatio-temporal dynamics. This was overcome for comparisons of natural and disturbance con- trols by analyzing data for each time of sampling separately. For comparisons of the treatment with detritus added and the natural control treatment, interpretations were made using the significant time $\times$ detritus enrichment interaction. In the one case where this interaction was not significant (i.e. Leitoscolopolos robustus), a denominator for the F-ratio was estimated to enable comparison among treatments (see Sokal \& Rohlf 1995).

\section{RESULTS}

\section{Variation in annelid assemblages}

A total of 22 species were identified from the 12801 annelids found during the field sampling. The structures of these annelid assemblages were extremely variable in space and time. Multivariate comparisons of assemblages showed a significant interaction between sites and time of sampling (Table 1). Similar results were achieved by univariate comparisons of species richness and the abundance of common annelid assemblages (Table 2, Fig. 1). Only Capitella capitata showed variation among sites that was relatively consistent through time (Table 2, Fig. 1).

There appeared to be 3 distinct periods in the development of annelid assemblages (Fig. 1). First, there were large changes in species richness and in abundance of common species in May and June. The 2 numerically dominant species increased greatly, with Streblospio benedicti following Paranais litoralis in the timing of peak maximum abundance. There were then

Table 2. Analyses of variance of the number of annelid species and the abundances of common annelids ( $\mathrm{n}=5$ replicate cores) sampled between May 2001 and Jan 2002. T: comparison between randomly-chosen sampling dates; S: comparison between randomly-chosen sites

\begin{tabular}{|c|c|c|c|c|c|c|c|}
\hline & $\mathrm{df}$ & MS & $F$ & $\mathrm{p}$ & MS & $F$ & $\mathrm{p}$ \\
\hline & & \multicolumn{3}{|c|}{ Species richness } & \multicolumn{3}{|c|}{ Paranais litoralis } \\
\hline $\mathrm{T}$ & 12 & 11.11 & 5.00 & $<0.01$ & 28.43 & 16.29 & $<0.01$ \\
\hline $\mathrm{S}$ & 3 & 38.33 & 17.24 & $<0.01$ & 10.46 & 6.00 & $<0.01$ \\
\hline $\mathrm{T} \times \mathrm{S}$ & 36 & 2.22 & 1.92 & $<0.01$ & 1.75 & 4.20 & $<0.01$ \\
\hline Res & 208 & 1.16 & & & 0.42 & & \\
\hline & & \multicolumn{3}{|c|}{ Capitella capitata } & \multicolumn{3}{|c|}{ Streblospio benedicti } \\
\hline $\mathrm{T}$ & 12 & 10.37 & 20.16 & $<0.01$ & 6.84 & 4.98 & $<0.01$ \\
\hline $\mathrm{S}$ & 3 & 3.29 & 6.40 & $<0.01$ & 8.56 & 6.23 & $<0.01$ \\
\hline $\mathrm{T} \times \mathrm{S}$ & 36 & 0.51 & 1.33 & 0.11 & 1.37 & 2.82 & $<0.01$ \\
\hline \multirow[t]{2}{*}{ Res } & 208 & 0.39 & & & 0.49 & & \\
\hline & & \multicolumn{3}{|c|}{ Leitoscolopolos robustus } & \multicolumn{3}{|c|}{ Nereis succinea } \\
\hline $\mathrm{T}$ & 12 & 1.36 & 1.89 & 0.07 & 3.02 & 5.00 & $<0.01$ \\
\hline S & 3 & 12.38 & 17.15 & $<0.01$ & 1.37 & 2.27 & 0.10 \\
\hline $\mathrm{T} \times \mathrm{S}$ & 36 & 0.72 & 1.96 & $<0.01$ & 0.60 & 3.67 & $<0.01$ \\
\hline Res & 208 & 0.37 & & & 0.16 & & \\
\hline
\end{tabular}



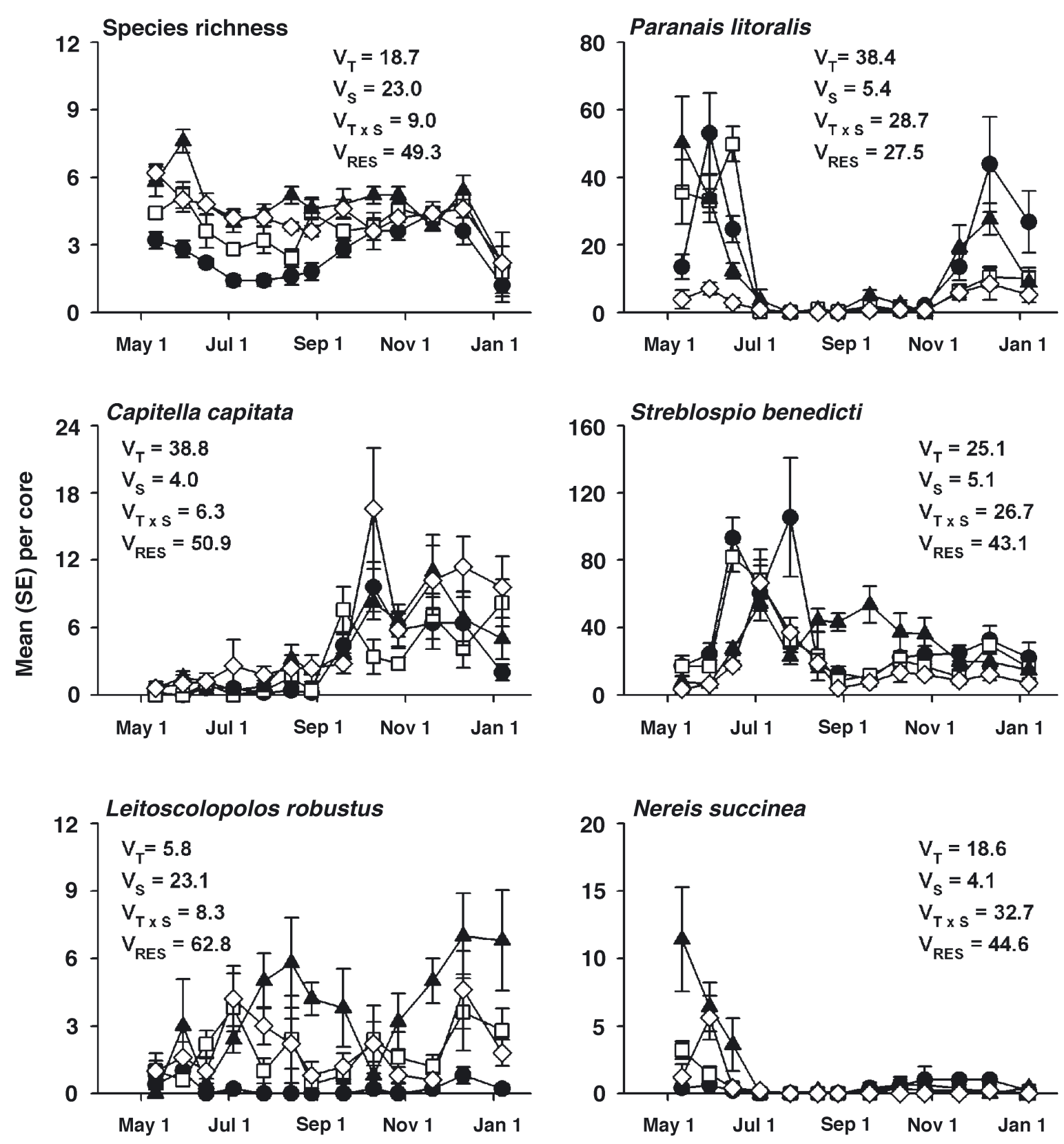

Fig. 1. Mean (SE, $\mathrm{n}=5$ replicate cores) species richness of annelids and abundance of common annelids in sites sampled between May 2001 and January 2002. $\bullet, \square, \mathbf{\Delta}, \diamond$ : Sites 1 to 4, respectively. Also shown are components of variation attributable to time of sampling $\left(\mathrm{V}_{\mathrm{T}}\right)$, sites $\left(\mathrm{V}_{\mathrm{S}}\right)$, interaction of sampling times and sites $\left(\mathrm{V}_{\mathrm{T} \times \mathrm{S}}\right)$ and replicate cores $\left(\mathrm{V}_{\mathrm{RES}}\right)$

sharp declines in both species, followed by a relatively stable period until mid-October in which there were only relatively small changes in annelid assemblages. Subsequently, there was another dynamic period, starting in mid-October, during which the abundances of the opportunistic species, $P$. litoralis and Capitella capitata showed large fluctuations in abundance. There were 2 exceptions to this pattern: first, C. capitata was only found in low abundance from May to
September; and second, the abundance of the deepfeeding orbinid polychaete Leitoscolopolos robustus, was relatively stable for most of the year (Fig. 1).

For the surface-feeding annelids Paranais litoralis, Streblospio benedicti and Nereis succinea, the greatest change in abundance in sites relative to each other occurred in May, June and July (Fig. 1). For the 2 dominant species, $P$. litoralis and $S$. benedicti, the population variances are clearly best explained by variation 


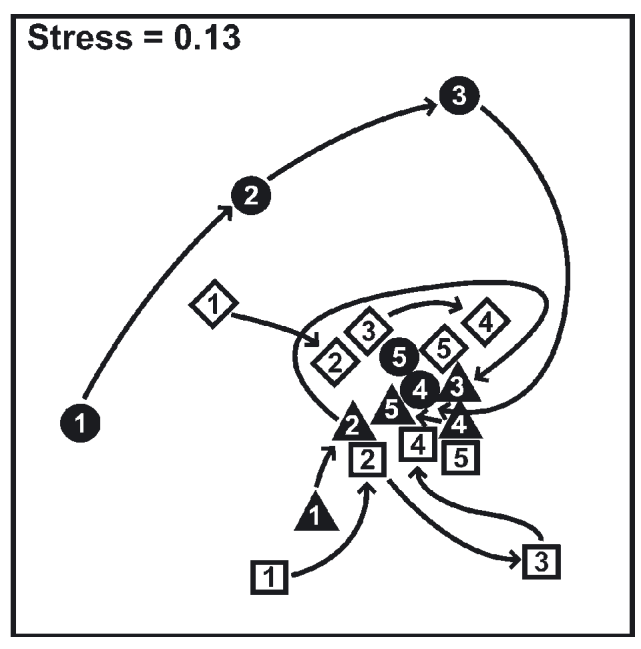

Fig. 2. Two-dimensional nMDS ordination tracking changes in annelid assemblages between May 2001 and July 2001. $\square, \boldsymbol{\Lambda}, \diamond$ : Sites 1 to 4 , respectively; Nos. 1 to 5: assemblages on May 10, May 29, June 13, July 3 and July 24, respectively. Data averaged for each site

in time and by the space-time interaction (combined total of $67 \%$ for P. litoralis and $52 \%$ for $S$. benedicti). In contrast, the sum of time-associated and space-time variance components were relatively small for the deeper-feeding Leitoscolopolos robustus (13\%). For this species, spatial variation was relatively more important $(23 \%)$.

An nMDS plot of site averages for the first 5 times of sampling demonstrates the development of annelid assemblages during the dynamic period in spring (Fig. 2). While it appears that annelid assemblages at all sites converged by mid-July, they clearly took very different paths getting there. During the first 3 sampling times, the annelid assemblage at each site differed substantially from those at other sites for at least 1 time of sampling. The most extreme example is Site 1, whose annelid assemblages deviated massively from those at other sites. The variation in direction and magnitude of changes in annelids between sites would certainly contribute to the significant multivariate site $\times$ time interaction in Table 1 .

The highest component of variation in annelid assemblages occurred at the level of cores (Table 1). The site $\times$ time interaction contributed the next biggest component of variation, and this was followed by pure temporal variation. Finally, pure spatial variation among sites accounted for the least amount of variation in multivariate analyses of macrofaunal assemblages (Table 1). Overall, the relative change in annelid assemblages in sites over time explained much more of the total variation than consistent site-to-site variation. Similar patterns were shown by the surface-feeding polychaetes, Paranais litoralis, Streblospio benedicti and Nereis succinea, although this was not the case for, Capitella capitata and Leitoscolopolos robustus (Fig. 1).

\section{Effects of surface anoxia on structure of annelid assemblages}

Anoxic conditions up to the sediment-water interface strongly affected annelid assemblages (NPMANOVA, pseudo- $F_{2,6}=3.88, p<0.001$, Fig. 3). Assemblages in plots with oxic conditions were significantly different from those in plots with natural and detritus-induced anoxic conditions (pair-wise tests, $\mathrm{p}<0.01$ ), which did not differ (pair-wise tests, $\mathrm{p}=0.67$, Fig. 3). This result is further supported by Fig. 3, which shows substantial separation between annelid assemblages in anoxic and in oxic sediment. This plot also appears to show that variation among cores is greater in anoxic plots than in non-anoxic plots. Analysis of multivariate dispersion demonstrated, however, that variation in annelid assemblages did not significantly differ among treatments (NP-DISP, pseudo- $F_{2,6}=2.63$, $\mathrm{p}=0.15$ ).

In nearly all cases, the diversity and abundance of annelids were substantially less in anoxic sediment than in oxic sediment, although these differences were only significant for species richness and the abundance of Paranais litoralis and Streblospio benedicti (Table 3, Fig. 4). Only the densities of Capitella capitata appear to have been unaffected by anoxia, although the abundance of this worm was extremely low at the time of this

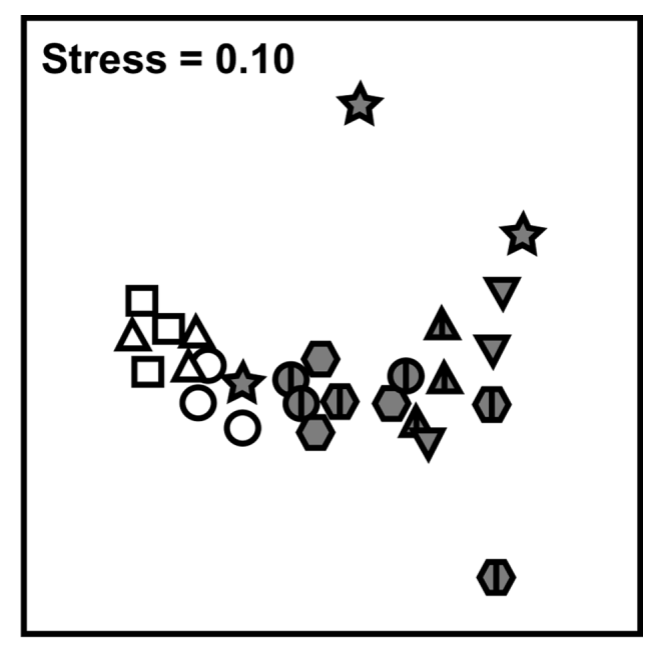

Fig. 3. Two-dimensional nMDS ordination comparing annelid assemblages in experimentally-induced anoxic sediment (gray symbols), naturally anoxic (divided gray symbols) and oxic (open symbols) sediment. Different-shaped symbols represent different sites nested in each treatment 
experiment (Table 3, Fig. 4). For all analyses, there were no significant differences between natural (as indicated by surface microbial mats) and experimentally-induced anoxic conditions (Table 3, Fig. 4), indicating that Ulva rotundata addition created an anoxic disturbance similar to that found naturally on the mud flat.

\section{Effect of detrital enrichment on development of annelid assemblages}

No differences were detected between annelid assemblages in undisturbed and manually disturbed sediment on any of the 6 sampling occasions (Fig. 5). Similar results were
Table 3. ANOVAs comparing number of annelid species and abundance of common annelids ( $\mathrm{n}=3$ replicate cores) in experimentally-induced anoxic, naturally anoxic and oxic sediments. TR: fixed comparison among treatments; S: comparison between randomly-chosen sites; Res: residual

\begin{tabular}{|c|c|c|c|c|c|c|c|}
\hline & $\mathrm{df}$ & MS & $F$ & $\mathrm{p}$ & MS & $F$ & $\mathrm{p}$ \\
\hline & & \multicolumn{3}{|c|}{ Species richness } & \multicolumn{3}{|c|}{ Paranais litoralis } \\
\hline TR & 2 & 26.70 & 6.27 & 0.03 & 756.26 & 7.27 & 0.02 \\
\hline $\mathrm{S}(\mathrm{TR})$ & 6 & 4.26 & 4.26 & 0.01 & 104.04 & 1.03 & 0.44 \\
\hline \multirow[t]{2}{*}{ Res } & 18 & 1.00 & & & 101.44 & & \\
\hline & & \multicolumn{3}{|c|}{ Capitella capitata } & \multicolumn{3}{|c|}{ Streblospio benedicti } \\
\hline TR & 2 & 1.17 & 0.49 & 0.64 & 24.03 & 18.45 & $<0.01$ \\
\hline $\mathrm{S}(\mathrm{TR})$ & 6 & 2.39 & 6.77 & $<0.01$ & 1.30 & 1.86 & 0.14 \\
\hline \multirow[t]{2}{*}{ Res } & 18 & 0.35 & & & 0.70 & & \\
\hline & & \multicolumn{3}{|c|}{ Leitoscolopolos robustus } & \multicolumn{3}{|c|}{ Nereis succinea } \\
\hline TR & 2 & 2.43 & 3.16 & 0.12 & 1.82 & 2.77 & 0.14 \\
\hline $\mathrm{S}(\mathrm{TR})$ & 6 & 0.77 & 3.12 & 0.03 & 0.66 & 4.06 & 0.01 \\
\hline Res & 18 & 0.25 & & & 0.16 & & \\
\hline
\end{tabular}
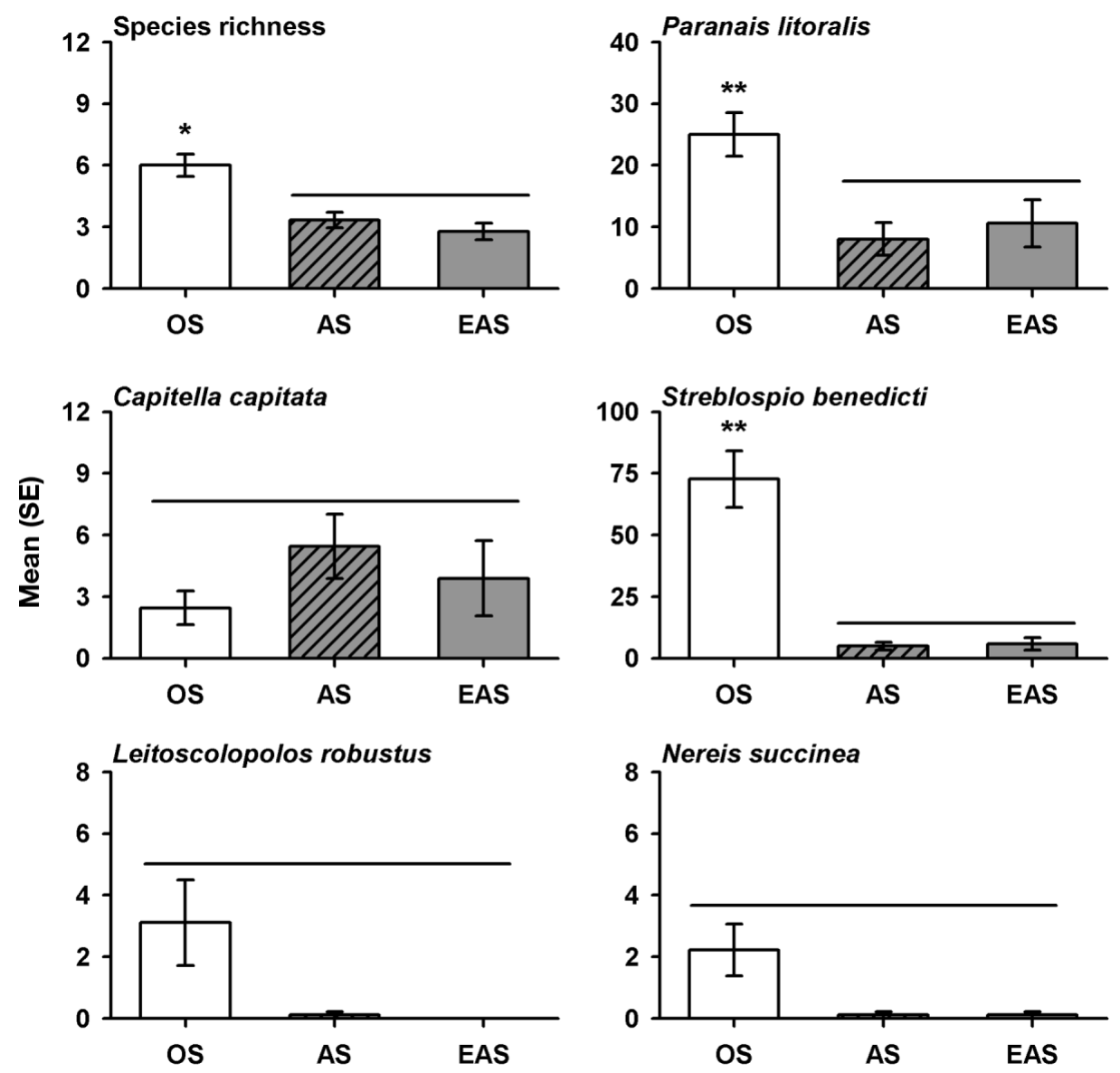

Fig. 4. Mean ( $\mathrm{SE}, \mathrm{n}=3$ replicate sites) richness of annelids and abundance of common annelids in experimentally-induced anoxic sediment (EAS) and naturally anoxic (AS) and oxic (0S) sediment. Results of SNK tests indicated above the bars: ${ }^{*} p<0.05$; ${ }^{* *} \mathrm{p}<0.01 ;-\mathrm{p}>0.05$ 

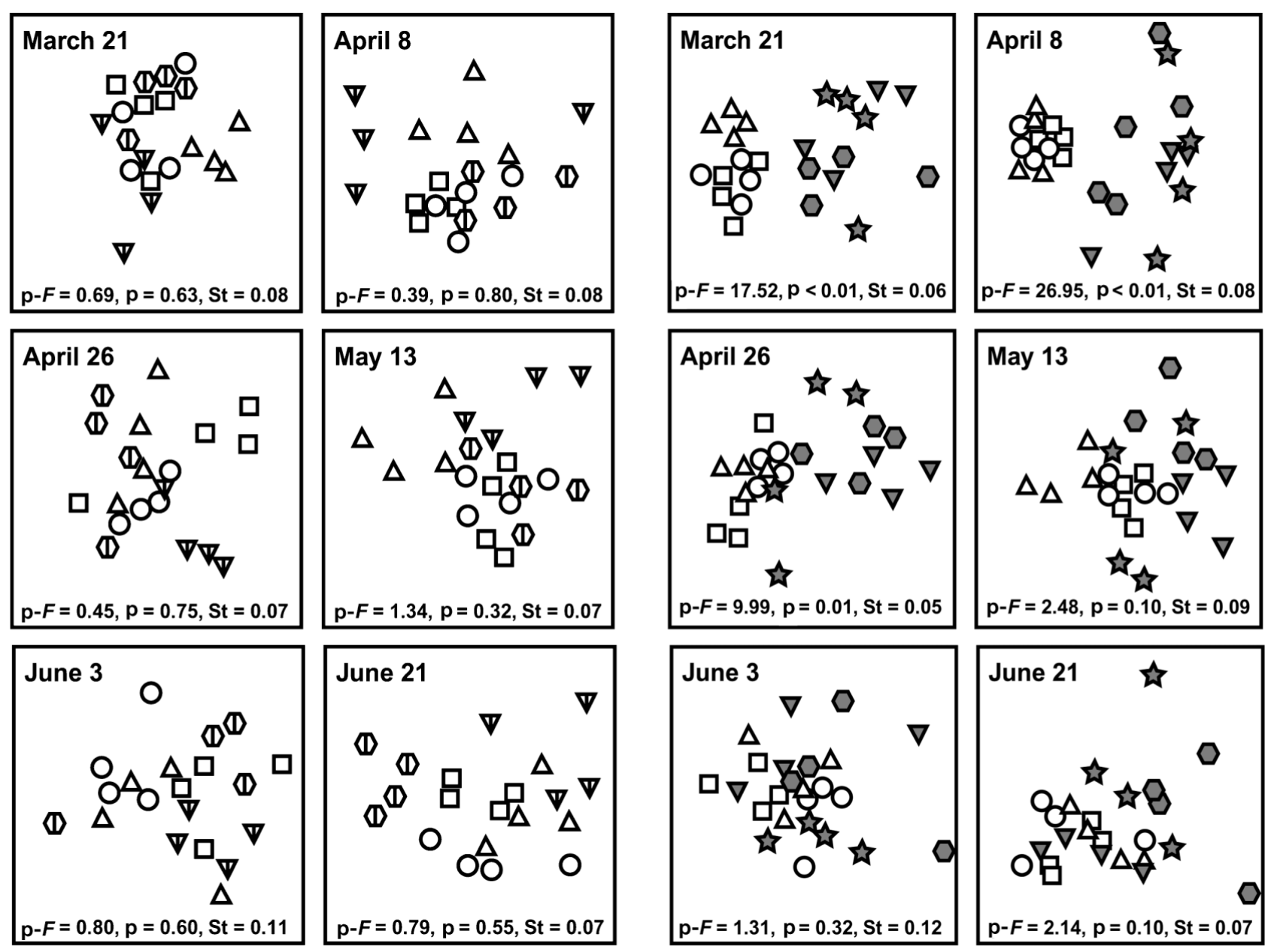

Fig. 5. Two-dimensional nMDS ordination comparing annelid assemblages in undisturbed (open symbols) and manually disturbed (divided symbols) sediments. Different-shaped symbols represent different sites nested in each treatment. Results of NP-MANOVA tests comparing treatments are indicated for each time of sampling. p-F: pseudo- $F$; St: stress

Fig. 6. Two-dimensional nMDS ordination comparing annelid assemblages in undisturbed (open symbols) and detritusenriched (gray symbols) sediments. Different-shaped symbols represent different sites nested in each treatment. Results of NP-MANOVA tests comparing treatments are indicated for each time of sampling. p-F: pseudo- $F$; St: stress

shown by univariate analyses of the diversity and abundance of annelids (Table 4). The only exception to these general results was Capitella capitata at the

fourth time of sampling (Table 4). However, given the large number of comparisons, it is probable that this was simply a Type 1 error rather than an explainable

Table 4. Unbalanced ANOVAs comparing number of annelid species and abundance of common annelids ( $\mathrm{n}=4$ replicate cores) in undisturbed and manually disturbed sites at the 6 times of sampling. Table shows F-ratio and p-value of treatment comparisons tested over nested factor of sites (3 undisturbed, 2 manually disturbed)

\begin{tabular}{|c|c|c|c|c|c|c|c|c|c|c|c|c|}
\hline & \multicolumn{2}{|c|}{ Time 1} & \multicolumn{2}{|c|}{ Time 2} & \multicolumn{2}{|c|}{ Time 3} & \multicolumn{2}{|c|}{ Time 4} & \multicolumn{2}{|c|}{ Time 5} & \multicolumn{2}{|c|}{ Time 6} \\
\hline & $F$ & $\mathrm{p}$ & $F$ & $\mathrm{p}$ & $F$ & $\mathrm{p}$ & $F$ & $\mathrm{p}$ & $F$ & $\mathrm{p}$ & $F$ & $\mathrm{p}$ \\
\hline Species richness & 5.60 & 0.10 & 0.40 & 0.57 & 2.34 & 0.22 & 1.10 & 0.37 & 1.69 & 0.28 & 1.25 & 0.35 \\
\hline Paranais litoralis & 0.94 & 0.40 & 1.10 & 0.37 & 1.47 & 0.31 & 4.06 & 0.14 & 0.06 & 0.83 & 1.60 & 0.30 \\
\hline Streblospio benedicti & 0.21 & 0.68 & 0.07 & 0.80 & 0.01 & 0.95 & 0.02 & 0.91 & 0.52 & 0.52 & 0.61 & 0.49 \\
\hline Capitella capitata & 0.12 & 0.75 & 0.60 & 0.50 & 2.21 & 0.23 & 18.46 & 0.02 & 0.18 & 0.70 & 0.89 & 0.41 \\
\hline Leitoscolopolos robustus & 1.80 & 0.27 & 0.18 & 0.70 & 0.11 & 0.76 & 0.37 & 0.58 & 0.33 & 0.61 & 1.33 & 0.33 \\
\hline Nereis succinea & 0.02 & 0.90 & 0.13 & 0.75 & 0.31 & 0.62 & 8.08 & 0.06 & 0.57 & 0.50 & 0.21 & 0.70 \\
\hline
\end{tabular}




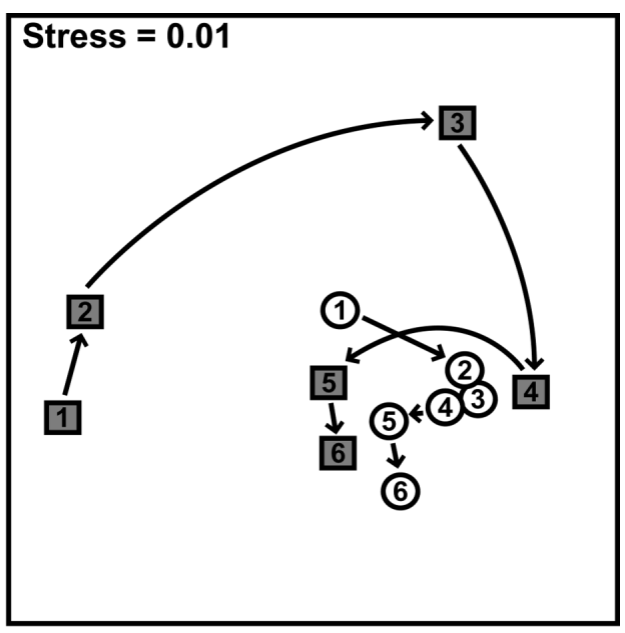

Fig. 7. Two-dimensional nMDS ordination tracking changes in annelid assemblages in undisturbed $(O)$ and detritusenriched $(\square)$ sediments. Nos. 1 to 6: assemblages on March 21, April 8, April 26, May 13, June 3, July 21, respectively. Data averaged for each treatment

effect. Overall, it appeared that the manual disturbance associated with Ulva rotundata addition had few, if any, lasting effects on the development of annelid assemblages. Consequently, this control treatment was excluded from further analyses.

There were significant differences between assemblages of annelids in sediment with enhanced detritus and those in undisturbed sediment at the first 3 times of sampling, but no significant differences for the remaining 3 times of sampling (Fig. 6). Fig. 7 shows the temporal development of assemblages of annelids in the undisturbed control and detritus-enriched treatments. For the first 3 times of sampling, the average assemblages in each treatment took very different temporal paths. Nevertheless, by the fourth time of sampling, the structure of annelid assemblages had converged and followed similar paths. In many respects, this is similar to the field sampling results in 2001, although the convergence was somewhat earlier in the season.

The univariate comparisons reflect the multivariate results in that differences among treatments were not consistent in time (see significant time $\times$ treatment interactions in Table 5). Species richness was significantly de- pressed in the detritus-enriched treatment for the first 2 times of sampling, but after this resembled the richness of species in undisturbed sediment (Fig. 8). A similar depression was shown in the abundance of Paranais litoralis for the first 2 times of sampling and in the abundance of Streblospio benedicti for the first 3 times of sampling. Almost certainly, these effects are related to anoxic conditions associated with adding detritus, as white sulfur bacteria were present on the surface of the sediment for the first 2 times of sampling. At the third time of sampling, there was a dramatic increase in the abundance of the opportunistic annelids $P$. littoralis and Capitella capitata. The orbinid polychaete, Leitoscolopolos robustus, was the only species not to respond to the addition of Ulva rotundata.

\section{DISCUSSION}

The compositions of annelid assemblages at Flax pond were extremely variable in space and time. The general seasonal patterns were similar to those reported for previous studies of intertidal mud flats in New England (e.g. Cheng et al. 1993, Nilsson et al. 1997) in that there was a spring boom in which surfacefeeding annelids peaked in abundance. This was fol-

Table 5. ANOVAs comparing number of annelid species and abundance of common annelids ( $\mathrm{n}=4$ replicate cores) in undisturbed and detritus-enriched sediments. T: comparison of 6 randomly chosen times of sampling; D: fixed comparison between undisturbed and detritus-enriched sediments; $\mathrm{S}$ : comparison between sites nested within $\mathrm{D}_{\text {; }}$ Res: residual, nt: no test

\begin{tabular}{|c|c|c|c|c|c|c|c|}
\hline & df & MS & $F$ & $\mathrm{p}$ & MS & $F$ & $\mathrm{p}$ \\
\hline & & \multicolumn{3}{|c|}{ Species richness } & \multicolumn{3}{|c|}{ Paranais litoralis } \\
\hline $\mathrm{T}$ & 5 & 12.79 & 13.44 & $<0.01$ & 28.66 & 37.35 & $<0.01$ \\
\hline $\mathrm{D}$ & 1 & 14.06 & nt & nt & 8.69 & nt & nt \\
\hline $\mathrm{S}(\mathrm{D})$ & 4 & 4.53 & 4.77 & $<0.01$ & 1.58 & 2.06 & 0.12 \\
\hline $\mathrm{T} \times \mathrm{D}$ & 5 & 10.11 & 10.63 & $<0.01$ & 12.26 & 15.98 & $<0.01$ \\
\hline $\mathrm{T} \times \mathrm{S}(\mathrm{D})$ & 20 & 0.95 & 1.14 & 0.32 & 0.77 & 2.13 & $<0.01$ \\
\hline \multirow[t]{2}{*}{ Res } & 108 & 0.84 & & & 0.36 & & \\
\hline & & \multicolumn{3}{|c|}{ Capitella capitata } & \multicolumn{3}{|c|}{ Streblospio benedicti } \\
\hline $\mathrm{T}$ & 5 & 7.55 & 10.64 & $<0.01$ & 8.20 & 31.60 & $<0.01$ \\
\hline $\mathrm{D}$ & 1 & 17.27 & $\mathrm{nt}$ & nt & 45.80 & nt & nt \\
\hline $\mathrm{S}(\mathrm{D})$ & 4 & 0.70 & 0.98 & 0.44 & 1.26 & 4.85 & $<0.01$ \\
\hline $\mathrm{T} \times \mathrm{D}$ & 5 & 10.29 & 14.49 & $<0.01$ & 5.76 & 22.20 & $<0.01$ \\
\hline $\mathrm{T} \times \mathrm{S}(\mathrm{D})$ & 20 & 0.71 & 1.32 & 0.18 & 0.26 & 0.55 & 0.94 \\
\hline \multirow[t]{2}{*}{ Res } & 108 & 0.54 & & & 0.47 & & \\
\hline & & \multicolumn{3}{|c|}{ Leitoscolopolos robustus } & \multicolumn{3}{|c|}{ Nereis succinea } \\
\hline $\mathrm{T}$ & 5 & 2.64 & 4.07 & 0.01 & 0.75 & 3.92 & 0.01 \\
\hline $\mathrm{D}$ & 1 & 0.13 & 0.04 & 0.84 & 7.12 & nt & nt \\
\hline $\mathrm{S}(\mathrm{D})$ & 4 & 2.63 & 4.05 & 0.01 & 1.11 & 5.85 & $<0.01$ \\
\hline $\mathrm{T} \times \mathrm{D}$ & 5 & 0.85 & 1.30 & 0.30 & 0.60 & 3.17 & 0.03 \\
\hline $\mathrm{T} \times \mathrm{S}(\mathrm{D})$ & 20 & 0.65 & 2.05 & $<0.01$ & 0.19 & 0.76 & 0.76 \\
\hline Res & 108 & 0.32 & & & 0.25 & & \\
\hline
\end{tabular}



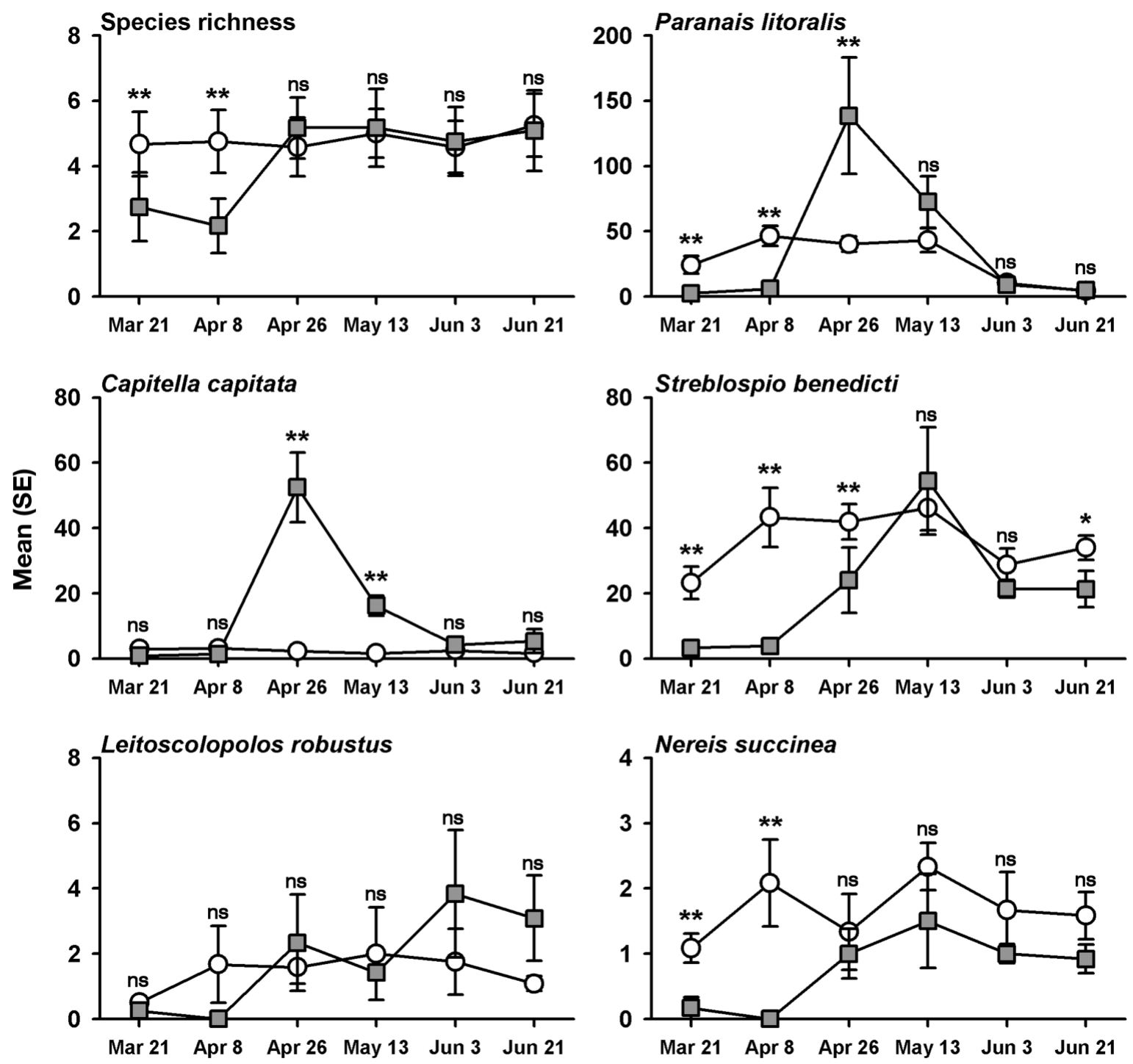

Fig. 8. Mean ( $\mathrm{SE}, \mathrm{n}=3$ replicate sites) richness of annelids and abundance of common annelids in undisturbed (O) and detritusenriched ( $\square$ ) sediments. Data are averaged for each treatment. Results of SNK tests are indicated for each time of sampling: ${ }^{*} \mathrm{p}<0.05 ;{ }^{* *} \mathrm{p}<0.01, \mathrm{~ns}$ : not significant at $\mathrm{p}>0.05$

lowed by severe crashes in some populations around June/July and a stable period with low annelid abundances over summer. Finally, there was an increase in the abundance of opportunistic species just before the coldest months in late fall/early winter.

At Flax Pond, the spring boom is probably initiated by a high deposition of algal and saltmarsh detritus and a low decomposition rate over the winter period (Levinton \& Stewart 1988, Cheng et al. 1993). The combination of these factors creates an ideal environment for microbial productivity and population growth of deposit-feeding invertebrates when temperatures increase in March (Levinton 1985, Lopez \& Levinton 1987). Nevertheless, these excess detrital resources usually run out in early summer and microbial production decreases, closely followed by crashes in populations of opportunistic deposit-feeders (Marsh \& Tenore 1990, Cheng et al. 1993). It is also possible that a seasonal increase in predation of annelids by fishes and crabs in late spring contributes to the demise and suppression of annelid abundances in some systems. However, caging experiments have shown that these predation effects are negligible at Flax Pond (Cheng et al. 1993).

The general seasonal patterns of annelids are perhaps best demonstrated by the numerically dominant annelids, Paranais litoralis and Streblospio benedicti, which showed highest abundance during the spring 
boom, followed by a massive population crash in June/July. Generally, the abundance peak of P. litoralis precedes that of $S$. benedicti, which is probably attributable to differences in reproductive biology: $P$. litoralis reproduces asexually by naidian paratomy, which permits rapid population growth (Nilsson et al. 1997, 1999), whereas $S$. benedicti in this area reproduces sexually and has planktotrophic rather than lecithotrophic larvae (see Levin \& Creed 1986 for details), which may delay initial recruitment into adult populations at the beginning of spring.

Although the exact timing of the crash varies from year to year, the abundance of the oligochaete Paranais litoralis consistently decreases several weeks prior to, and with much greater magnitude than, the decrease in abundance of the spionid polychaete Streblospio benedicti. Because these deposit-feeding species generally obtain most of their nutritional needs from microorganisms at or near the sediment-water interface (Lopez \& Levinton 1987), the timing and strength of these crashes provides relatively strong evidence for resource-limitation when the microbial productivity decreases dramatically in June. The greater subsequent survival of $S$. benedicti over $P$. litoralis is probably attributable to the former's larger biomass and spionid feeding flexibility, which can include the capture of suspended particles from the water column (Taghon et al. 1980, Dauer \& Ewing 1991, Taghon 1992, Dauer 2000). Further experiments are, however, required before the exact mechanism can be determined.

While our results show that disturbance in general can cause variation among annelid assemblages in sites separated by 10 s of meters, the relative importance of effects depended on the type of disturbance applied to the system. For example, physicochemical disturbance of anoxic conditions at the surface-water interface substantially reduced the diversity and abundance of annelids. In contrast, our simulation of a localized physical disturbance by hand-churning the sediment surface had no detectable effect on annelids. Small physical disturbances from burrowing crustaceans and benthic fishes are common in softsediment habitats (Levin 1984, Thrush et al. 1991). Our results show that annelid assemblages at Flax Pond are relatively resilient to these small-scale disturbances at the intensity used in our treatments.

Although annelid assemblages varied significantly among sites separated by 10 s of meters, the patterns and magnitudes of these differences varied substantially from time to time. As well as significant site $\times$ time interactions, this was strongly reflected in the variance components. In these analyses, the spatiotemporal component of variation contributed much more to the total variation than the pure spatial component, which is what would be expected if the system resembled a mosaic of patches rather than a rigid spatial structure. These results emphasize the importance of processes that act on short-term temporal scales (e.g. disturbances, detritus inputs and recruitment events) rather than those that operate consistently over long time periods (e.g. relatively permanent changes in the physicochemical environment).

While the most abundant annelids showed this pattern of variation, there were several notable exceptions. Probably the most important of these is the orbinid polycheate Leitoscolopolos robustus, which lives and feeds more deeply in the sediment than the other common species investigated (Bianchi 1988, Bianchi \& Rice 1988). In many respects, L. robustus appears to represent a stable element at all sites because, in contrast to the surface feeders, it showed less spatio-temporal and temporal variation. Bioturbation of this deep-feeding species contributes to diagenesis of organic matter, resulting in a suite of more slowly degrading fractions deeper into the sediment (Mayer \& Rice 1992). On the other hand, burrowing activities of this species may promote positive feedback toward the surface, enhancing microbial activity for surface feeders (Bianchi et al. 1989). Thus, in the long run, activities of this deeper feeder might subsidize surface feeders.

From an examination of the field sampling data, it appears that the mud flats at Flax Pond during the spring boom are perhaps best described by Johnson's (1970) hypothesis of a mosaic of patches. This description does not, however, represent community dynamics during summer and fall, when spatio-temporal variation among sites was small. This is perhaps most clearly seen in the MDS plot that tracked the development of annelid assemblages and showed a convergence of sites in July, after fluctuating during spring. Although a number of factors may be responsible for these intriguing seasonal patterns of inter-site variation, we hypothesize that spatial variation in the deposition of detritus has a large influence, because (1) the population abundance of surface deposit-feeders is resource-limited (Levinton \& Stewart 1988, B. P. Kelaher et al. unpubl. data), (2) the nutritive quality of the sediment is higher but may be more spatio-temporally variable in spring than in summer (Cheng et al. 1993, Cheng \& Chang 1999), and (3) the magnitudes of local increases in population abundances during spring are directly proportional to available resources (Levinton \& Stewart 1982, 1988)

Inputs of algal detritus can clearly influence patterns of spatial and temporal variation of micro- and macrofaunal assemblages in soft-sediment habitats (Tenore 1977, Cheng et al. 1993, Raffaelli et al. 1998, Rossi \& 
Underwood 2002). Our study shows that detrital enrichment and anoxic disturbance contributes to the substantial spatial variation in annelid assemblages at the scale of 10 s of meters. More than this, however, our study demonstrates that simple spatial variation in the deposition of detritus can also generate the complicated spatio-temporal patterns observed in natural systems. This study, therefore, highlights the important role of interactions generated by the bottom-up force of localized macroalgal detrital food input and its indirect short-term consequence of surface anoxic disturbance in generating the complex patterns of benthic community structure in soft-sediment habitats.

Acknowledgements. This study was supported by grants from the Hudson River Foundation and the National Science Foundation. We are grateful to Isabel Ashton, Ruth Junkins, Maggie Fung and Bengt Allen for help with field and laboratory work. We would also like to thank Les Watling and 2 anonymous reviewers for their helpful comments.

\section{LITERATURE CITED}

Anderson MJ (2001) A new method for non-parametric multivariate analysis of variance in ecology. Aust $\mathrm{J}$ Ecol 26: $32-46$

Azovsky AI, Chertoprood MV, Kucheruk NV, Rybnikov PV, Sapozhnikov FV (2000) Fractal properties of spatial distribution of intertidal benthic communities. Mar Biol 136: 581-590

Barry JP, Dayton PK (1992) Physical heterogeneity and the organization of marine communities. In: Kolasa J, Pickett ST (eds) Ecological heterogeneity. Springer-Verlag, New York, p 270-320

Bianchi TS (1988) Feeding ecology of the subsurface depositfeeder Leitoscoloplos fragilis. I. Mechanisms affecting particle availability on an intertidal sandflat. J Exp Mar Biol Ecol 115:79-97

Bianchi TS, Levinton JS (1981) Nutrition and food limitation of deposit-feeders. 2. Differential-effects of Hydrobia totteni and Ilyanassa obsoleta on the microbial community. J Mar Res 39:547-556

Bianchi TS, Rice DL (1988) Feeding ecology of Leitoscoloplos fragilis. II. Effects of worm density on benthic diatom production. Mar Biol 99:123-131

Bianchi TS, Jones CG, Shachak M (1989) Positive feedback of consumer population-density on resource supply. Trends Ecol Evol 4:234-238

Bianchi TS, Johansson B, Elmgren R (2000) Breakdown of phytoplankton pigments in Baltic sediments: effects of anoxia and loss of deposit-feeding macrofauna. J Exp Mar Biol Ecol 251:161-183

Bolam SG, Fernandes TF, Read P, Raffaelli D (2000) Effects of macroalgal mats on intertidal sandflats: an experimental study. J Exp Mar Biol Ecol 249:123-137

Bray JR, Curtis JT (1957) An ordination of the upland forest communities of Southern Wisconsin. Ecol Monogr 27: 325-349

Chapman MG (1998) Relationships between spatial patterns of benthic assemblages in a mangrove forest using different levels of taxonomic resolution. Mar Ecol Prog Ser 162:71-78
Cheng IJ, Chang PC (1999) The relationship between surface macrofauna and sediment nutrients in a mudflat of the Chuwei mangrove forest, Taiwan. Bull Mar Sci 65:603-616

Cheng IJ, Levinton JS, McCartney M, Martinez D, Weissburg MJ (1993) A bioassay approach to seasonal variation in the nutritional value of sediment. Mar Ecol Prog Ser 94: 275-285

Dauer DM (2000) Functional morphology and feeding behavior of Spio setosa (Polychaeta : Spionidae). Bull Mar Sci 67: 269-275

Dauer DM, Ewing RM (1991) Functional morphology and feeding behavior of Malacoceros indicus (Polychaeta, Spionidae). Bull Mar Sci 48:395-400

Diaz RJ, Rosenberg R (1995) Marine benthic hypoxia: a review of its ecological effects and the behavioural responses of benthic macrofauna. Oceanogr Mar Biol Annu Rev 33:245-303

Field JG, Clarke KR, Warwick RM (1982) A practical strategy for analysing multispecies distribution patterns. Mar Ecol Prog Ser 8:37-52

Findlay S, Tenore K (1982) Nitrogen source for a detritivoredetritus substrate versus associated microbes. Science 218:371-373

Gray JS (1974) Animal-sediment relationships. Oceanogr Mar Biol 12:223-261

Hull SC (1987) Macroalgal mats and species abundance-a field experiment. Estuar Coast Shelf Sci 25:519-532

Johnson RG (1970) Variations in diversity within benthic marine communities. Am Nat 104:285-300

Kelaher B, Chapman MG, Underwood AJ (2001) Spatial patterns of diverse macrofaunal assemblages in coralline turf and their association with environmental variables. J Mar Biol Assoc UK 81:1-14

Kelaher BP, Levinton JS, Hoch JM (2003) Foraging by the mud snail, Ilyanassa obsoleta (Say), modulates spatial variation in benthic community structure. J Exp Mar Biol Ecol 292:139-157

Levin LA (1984) Life-history and dispersal patterns in a dense infaunal polychaete assemblage-community structure and response to disturbance. Ecology 65:1185-1200

Levin LA, Creed EL (1986) Effect of temperature and food availability on reproductive responses of Streblospio benedicti (Polychaeta: Spionidae) with planktotrophic or lecithotrophic development. Mar Biol 92:103-113

Levinton JS (1985) Complex interactions of a deposit feeder with its resources - roles of density, a competitor, and detrital addition in the growth and survival of the mudsnail Hydrobia totteni. Mar Ecol Prog Ser 22:31-40

Levinton JS, Bianchi TS (1981) Nutrition and food limitation of deposit feeders. 1. The role of microbes in the growth of mud snails (Hydrobiidae). J Mar Res 39:531-545

Levinton JS, Stewart S (1982) Marine succession - the effect of two deposit-feeding gastropod species on the population growth of Paranais litoralis Muller, 1784 (Oligochaeta). J Exp Mar Biol Ecol 59:231-241

Levinton JS, Stewart S (1988) Effects of sediment organics, detrital input, and temperature on demography, production, and body size of a deposit feeder. Mar Ecol Prog Ser 49:259-266

Lopez GR, Levinton JS (1987) Ecology of deposit-feeding animals in marine sediments. Q Rev Biol 62:235-260

Marsh AG, Tenore KR (1990) The role of nutrition in regulating the population dynamics of opportunistic, surface deposit feeders in a mesohaline community. Limnol Oceanogr 35:710-724

Mayer LM, Rice DL (1992) Early diagenesis of protein: a seasonal study. Limnol Oceanogr 37:280-295 
McArdle BH, Anderson MJ (2001) Fitting multivariate models to community data: a comment on distance-based redundancy analysis. Ecology 82:290-297

Morrisey DJ, Howitt L, Underwood AJ, Stark JS (1992a) Spatial variation in soft-sediment benthos. Mar Ecol Prog Ser 81:197-204

Morrisey DJ, Underwood AJ, Howitt L, Stark JS (1992b) Temporal variation in soft-sediment benthos. J Exp Mar Biol Ecol 164:233-245

Nilsson P, Kurdziel JP, Levinton JS (1997) Heterogeneous population growth, parental effects and genotype-environment interactions of a marine oligochaete. Mar Biol 130:181-191

Nilsson PG, Levinton JS, Kurdziel JP (2000) Migration of a marine oligochaete: induction of dispersal and microhabitat choice. Mar Ecol Prog Ser 207:89-96

Nixon SW (1980) Between coastal marshes and coastal water: a review of twenty years of speculation and research on the role of saltmarshes in estuarine water chemistry and water chemistry. In: Hamilton E, MacDonald KB (eds) Estuarine and wetland processes. Plenum, New York, p 437-525

Olabarria C, Chapman MG (2001) Comparison of patterns of spatial variation of microgastropods between two contrasting intertidal habitats. J Exp Mar Biol Ecol 274: $121-140$

Olafsson EB, Peterson CH, Ambrose WG (1994) Does recruitment limitation structure populations and communities of macroinvertebrates in marine soft sediments - the relative significance of presettlement and postsettlement processes. Oceanogr Mar Biol Annu Rev 32:65-109

Peterson BJ, Howarth RW, Garritt RH (1986) Sulfur and carbon isotopes as tracers of salt marsh organic matter flow. Ecology 67:865-874

Raffaelli DG, Raven JA, Poole LJ (1998) Ecological impact of green macroalgal blooms. Oceanogr Mar Biol Annu Rev 36:97-125

Rhoads DC, McCall PL, Yingst JY (1978) Disturbance and production on estuarine seafloor. Am Sci 66:577-586

Robinson DL (1987) Estimation and use of variance components. Statistician 36:3-14

Rossi F, Underwood AJ (2002) Small-scale disturbance and increased nutrients as influences on intertidal macrobenthic assemblages: experimental burial of wrack in different intertidal environments. Mar Ecol Prog Ser 241:29-39

Rublee PA (1982) Seasonal distribution of bacteria in salt marsh sediments in North Carolina. Estuar Coast Shelf Sci 15:67-74

Snelgrove PVR, Butman CA (1994) Animal sediment relationships revisited-cause versus effect. Oceanogr Mar Biol Annu Rev 32:111-177

Sokal RR, Rohlf FJ (1995) Biometry. The principles and practice of statistics in biological research, 3rd edn, Freeman, New York

Taghon GL (1992) Effects of animal density and supply of deposited and suspended food particles on feeding, growth and small-scale distributions of two spionid polychaetes. J Exp Mar Biol Ecol 162:77-95

Editorial responsibility: Roger Hughes (Contributing Editor), Bangor, Wales, UK
Taghon GL, Nowell ARM, Jumars PA (1980) Induction of suspension feeding in spionid polychaetes by high particulate fluxes. Science 210:562-564

Tagliapietra D, Pavan M, Wagner C (1998) Macrobenthic community changes related to eutrophication in Palude della Rosa (Venetian lagoon, Italy). Estuar Coast Shelf Sci 47:217-226

Tenore KR (1977) Growth of Capitella capitata cultured on various levels of detritus derived from different sources. Limnol Oceanogr 22:936-941

Tenore KR, Chesney EJ (1985) The effects of interaction of rate of food supply and population density on the bioenergetics of the opportunistic polychaete, Capitella capitata (Type-1). Limnol Oceanogr 30:1188-1195

Thistle D (1981) Natural physical disturbances and communities of marine soft bottoms. Mar Ecol Prog Ser 6:223-228

Thrush SF (1991) Spatial patterns in soft-bottom communities. Trends Ecol Evol 6:75-79

Thrush SF, Pridmore RD, Hewitt JE, Cummings VJ (1991) Impact of ray feeding disturbances on sandflat macrobenthos: do communities dominated by polychaetes or shellfish respond differently. Mar Ecol Prog Ser 69:245-252

Thrush SF, Whitlatch RB, Pridmore RD, Hewitt JE, Cummings VJ, Wilkinson MR (1996) Scale-dependent recolonization: the role of sediment stability in a dynamic sandflat habitat. Ecology 77:2472-2487

Underwood AJ (1994) Things environmental scientists (and statisticians) need to know to receive (and give) better statistical advice. In: Fletcher D, Manly BFJ (eds) Statistics in ecology and environmental monitoring. University of Otago Press, Dunedin, p 33-61

Underwood AJ (1997) Experiments in ecology: their logical design and interpretation using analysis of variance. Cambridge University Press, Cambridge

Underwood AJ, Chapman MG (1996) Scales of spatial patterns of distribution of intertidal invertebrates. Oecologia 107:212-224

Underwood AJ, Chapman MG (1998) Spatial analyses of intertidal assemblages on sheltered rocky shores. Aust J Ecol 23:138-157

Wharfe JR (1977) Ecological survey of benthic invertebrate macrofauna of lower Medway Estuary, Kent. J Anim Ecol 46:93-113

Whitlatch RB, Lohrer AM, Thrush SF, Pridmore RD, Hewitt JE, Cummings VJ, Zajac RN (1998) Scale-dependent benthic recolonization dynamics: life stage based dispersal and demographic consequences. Hydrobiologia 376: 217-226

Winer BJ, Brown DR, Michels KM (1991) Statistical principles in experimental design. McGraw-Hill, New York

Woodin SA (1974) Polychaete abundance patterns in a marine soft-sediment environment-importance of biological interactions. Ecol Monogr 44:171-187

Zajac RN (2001) Organism-sediment relations at multiple spatial scales: implications for community structure and successional dynamics. In: Aller JY, Woodin SA, Aller RC (eds) Organism-sediment interactions. University of South Carolina Press, Columbia, SC, p 119-139

Submitted: January 25, 2003; Accepted: June 6, 2003

Proofs received from author(s): September 25, 2003 